\title{
Широм раширених руку
}

Горан Траиловић

Градска библиотека Панчево

goran@biblioteka-pancevo.org.rs

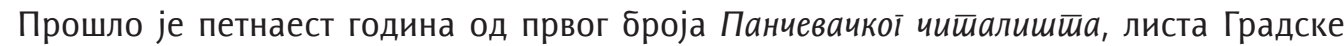
библиотеке Панчево, из новембра 2002. Много тога се променило: чланови редакције, концепција, број страна... па и само име.

С носталгијом листамо тај кламовани првенац на шездесетак страна који почиње уводном речи Немање Ротара, тадашњег директора Библиотеке, а завршава белешком о сликару Властимиру Николићу, аутору ликовних прилога. Његови „записи о ватри и ентропији” и „времену ништавила” дали су посебну ноту гласилу. Од „Мита о Прометеjу" у првом броју, до Шобајићевих „Широм раширених руку”, на корицама тридесетог, бројимо драгоцене прилоге наших савремених уметника. Хвала Мимици Алексић, нашем дугогодишњем ликовном уреднику на неисцрпној енергији и идеји да овако опре-

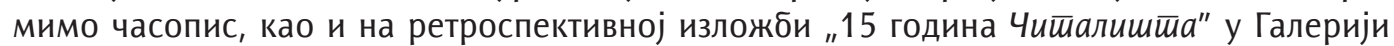

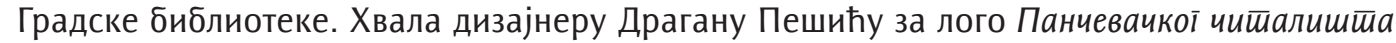

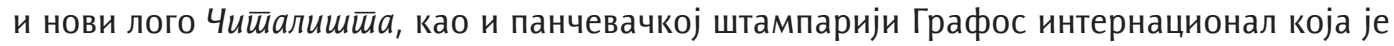
бесплатно одштампала први број.

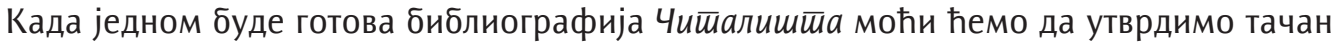
број сарадника, градова и држава из којих долазе. Процењујемо да их има више од 500 и да живе и раде у многим земљама широм Европе и света. Први број је у великој мери био посвећен панчевачкој библиотеци (рубрика Чишалишие), али је у њему било много сарадника из других библиотека: Народне библиотеке Србије (Весна Стевановић, Весна Ињац, Гордана Љубановић, Добрила Бегенишић, Дубравка Симовић), Библиотеке Матице српске (Жељко Вучковић, Марија Јованцаи), Универзитетске библиотеке у Београду (Стела Филипи-Матутиновић, Весна Жупан), Института за математику у Новом Саду (Гордана Рудић), Библиотеке града Београда (Јасмина Нинков, Љубица Ћоровић), Ужица (Драгана Божовић), Јагодине (Милун Васић), Смедерева (Драган Мрдаковић), Крагујевца (Гордана Вучковић), Крушевца (Соња Вељковић), Ковина (Душан Милић), Вршца (Весна Златичанин), Бора (Горан Миленковић)...

Текст о библиотеци Црквене општине Панчево потписао је наш колега Жарко Војновић који је касније „пребегао” у Народну библиотеку Србије. Њему дугујемо захвалност за пун ангажман у првим бројевима у својству лектора, члана редакције и техничког уредника (заједно са Иваном Абрамовић). Дужност лектора делио је са Надом Миловановић и некако смо, у жељи да објављујемо што квалитетнији часопис, лекторе највише „трошили". Многи су одустајали суочивши се са високим захтевима редакције, динамиком и озбиљношћу посла који су прихватили. Др Драгана Сабовљев најдуже се задржала на овој „ветрометини”, преузевши касније обавезе стручног редактора и уредника рубрике Библиошека, остајући она драгоцена радилица без које часопис не би имао овај квалитет. 
Знамо да смо утицали на библиотекарство у Србији и да се Градска библиотека

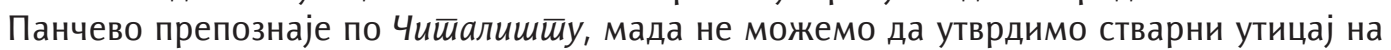
своју матичну установу и баштинске институције у граду. Један једини прилог из ових установа имали смо само у првом броју, из пера Милана Јакшића, угледног директора Историјског архива. У њему текстове из панчевачке библиотеке потписују: Ветурија Пушичић (завичајно одељење), Нада Миловановић (набавна служба), информатичар Ивана Абрамовић, Милован Лукић (уредник Библија), писац овог уводника - Горан Траиловић и Несиба Палибрк-Сукић, која ће у годинама које су следиле објавити већи број текстова о библиотеци и књигама руске колоније, Француског клуба и Пучке банке.

"Семе" посејано у првом броју пало је на плодно тло; Несиба Палибрк-Сукић је, у издању Библиотеке, објавила у међувремену три књиге, а у припреми су нове, потписник ових редова Личну шойоїрафију раја, Жарко Војновић, у „панчевачкој фази”, две књиге из области културне завичајне историје, а затим већи број текстова који се односе на црквено библиотекарство и Кућу на камену посвећену панчевачком манастиру у Војловици и његовим књигама... Чишалишеше је подстакло издавачку делатност стручне литературе у Библиотеци и привукло најугледније ауторе и ауторитете у својој области, попут проф. др Десанке Стаматовић.

Те 2002. године проф. др Гордана Стокић Симончић је у Панчеву објавила своју прву књигу, Ка филозофији библиошеккарсшива (коју је Жељко Вучковић приказао), али и прилог у рубрици Линк. Била нам је велика част што смо могли да међу угледне сараднике убројимо и једног професора са Катедре за библиотекарство и информатику Филолошког Факултета у Београду. Седам година касније постала је главни уредник и кормило часописа усмерава ка пучини науке о библиотекарству. Проф. др Жељко Вучковић, такође, постаје члан редакције у време када је напустио Библиотеку Матице српске и преузео прво само професуру, а затим и нашу другу катедру за библиотекарство на Педагошком факултету у Сомбору (чији је сада декан).

Министарство за науку и технолошки развој Републике Србије и Национални савет за научни и технолошки развој Чишалишеше су категоризовали као научни часопис (M53). Поносни смо на чињеницу да смо 2009. били први библиотекарски часопис који је добио научни ранг, а да смо од 2012. године часопис од националног значаја (M52). То је, наравно, имало своју цену: „коштало” је времена, труда, финансија и тешке борбе са Матичним научним одбором за језик и књижевност Министарства науке (које је одлуке о категоризацији доносило и ван прокламованих захтева и јавно доступних докумената, по неким својим интерним и неписаним правилима која нам нису била позната). Тада смо сазнали да је Министарство науку о библиотекарству „систематизовало" у корпус језика и књижевности. Како у том МНО није било ниједног стручњака из области библиотекарства, а нема га ни дан-данас, и нико да се сети да библиотекарство сврста у одговарајући матични одбор, часопис још увек чека вишу (и заслужену) категоризацију.

Чишалишеше је помогло многим нашим колегама да, на основу објављених текстова у њему, остваре своје право на стручна и академска звања. Она у библиотекама широм Србије (осим у Панчеву, нажалост) доносе одређену престиж, већа примања и друге бенефите. Али, рекао бих да је веза наших дугогодишњих сарадника са часописом и његовом редакцијом чин поверења и поштовања, које смо заслужили озбиљним приступом и принципијелном политиком јавно прокламованом и у пракси утврђеном.

Треба истаћи да часописа не би било без безрезервне подршке издавача, Градске библиотеке Панчево и Града Панчева, као и верних читалаца и претплатника (који сежу до лондонске и вашингтонске библиотеке). У тешким (финансијским) тренуцима, попут оног прошле године када нам је Министарство културе и информисања ускратило 
подршку, ово су били чврсти стубови и ослонци Чишалишша. Хвала Министарству на деценијској подршци (обновљеној ове године), као и на повременој, али значајној финансијској подршци Покрајинског секретаријата за културу.

На крају овог „времеплова” желели бисмо да изразимо захвалност члановима Савета часописа, рецензентима, представнику издавача Дејану Боснићу (директору Градске библиотеке Панчево) и нашем суиздавачу - Филозофском факултету у Новом Саду. Захвалност дугујемо и дугогодишњим сарадницима: Биљани Живановић (преводиоцу и редактору превода), Драгани Михаиловић (сараднику за стручну класификацију), Дуњи Шашић (дизајнеру и техничком уреднику) и вебмастерима Бранку Јевђићу (citaliste. com) и мстр Дамиру Симончићу (citaliste.rs).

Потписник овог јубиларног текста изражава дубоку захвалност свим поменутим и непоменутим ауторима, уредницима, сарадницима и библиотекарској заједници коју одавно доживљава као своју другу породицу и која му пружа онај потребни смисао и радост живљења и деловања у овој области. 